\title{
ENFERMAGEM E PSICOLOGIA: PARCERIA NA ARTE DO CUIDAR
}

\author{
$\underline{\text { SILVA, A.P.S }}^{1}$; SOUZA, B.O.R. ${ }^{1}$; ANDRADE, E.R. ${ }^{2}$ \\ ${ }^{1}$ Graduandos do Curso de Enfermagem , Institutos Superiores de Ensino do CENSA - ISECENSA, \\ Rua Salvador Correa, 139, Centro, Campos dos Goytacazes, RJ, Brasil. Email: ap.sss@ hotmail.com \\ ${ }^{2}$ Mestre, Docente dos Cursos de Psicologia, Pedagogia e Enfermagem dos Institutos Superiores de \\ Ensino do CENSA - ISECENSA, Rua Salvador Correa, 139, Centro, Campos dos Goytacazes, RJ, \\ Brasil. Email: ericahribeiro@yahoo.com.br
}

Introdução: A Psicologia é o estudo dos fenômenos psíquicos e do comportamento do ser humano por intermédio de análise de suas emoções, suas ideias e seus valores. É necessário aplicar a psicologia na área da enfermagem para que os futuros profissionais possam aprender e compreender um novo olhar ao estabelecer seu relacionamento com o paciente e também seus familiares, e não deixar essas práticas somente com o profissional da área de assistência social. Segundo Melo et.al. (2014), no que tange a relação entre Psicologia e Enfermagem, a Psicologia desempenha um papel importante na formação da área da saúde, marcada pelo desenvolvimento de uma profissionalização centrada na modernnização, cientifização e teorização das práticas profissionais, com o objetivo sobretudo de formar um novo perfil de enfermeiros e interferir no processo de organização e consolidação da disciplina no campo da enfermagem. Objetivo: Refletir sobre a relação entre a psicologia e a enfermagem num viés prático. Metodologia: Trata-se de um Relato de Experiência de um estudo de caso realizado na disciplina de Psicologia na Enfermagem no segundo semestre de 2014. Realizamos uma entrevista com uma enfermeira com 7 anos de experiência na profissão. Foram abordados assuntos relacionados à psicologia em sua área de atuação. Resultados: Para ela, ter a disciplina de psicologia na época de sua formação proporcionou um amplo conhecimento e um novo olhar para compreender e entender as situações emocionais de pacientes e seus familiares. Afirma que no cotidiano de trabalho de um enfermeiro é exigido não só conhecimento técnico para realização de suas condutas, mas acima de tudo um grande equilíbrio emocional para lidar com as divergências que certamente aparecerão para observar atentamente tudo àquilo que acontece em sua volta e poder concluir de maneira sutil qualquer problemática. Segundo a entrevistada, a psicologia direciona o enfermeiro para um campo mais amplo de atuação, onde o pensamento arcaico de que cuidar se restringe em apenas "colocar a mão sobre o paciente" para realização de procedimentos e técnicas vai perdendo espaço. Em contrapartida começa-se a adotar medidas que proporcione mais conforto e bem-estar por meio de atitudes que são aparentemente simples como estar mais perto do paciente nos mais variados momentos de sua hospitalização, principalmente em casos de pacientes deprimidos, onde o enfermeiro se faz do paciente seu constante acompanhante. Pensando sobre os vários aspectos emocionais que se apresentam no seu cotidiano, a entrevistada diz que há quem pense que o trabalho do enfermeiro se restrinja apenas ao paciente, mas é muito mais complexo, visto que geralmente cada um deles traz consigo um acompanhante, um membro de sua família, que sofre no aguardo de um pequeno gesto de melhora, de uma expressão que não haja dor, de um apoio que o sustente nessa trajetória tão difícil. Neste sentido é necessário o empenho do enfermeiro também no acolhimento a este ente querido que no momento se encontra em desamparo. A enfermeira afirma que os conhecimentos nessa área tão ampla que é a psicologia nos auxilia a sermos mais humanos no que diz respeito ao próximo, lidarmos com vida, que por um certo período se encontra fragilizada e sem motivação. Assim, a psicologia, acredita a enfermeira, é essencial para o vínculo de confiança e uma recuperação mais satisfatória desse paciente. Conclusões: Concluímos que a psicologia é relevante para que possamos ajudar na resolução dos problemas da nossa equipe, problemas que se possam estar ocorrendo não só no trabalho, mas também pessoalmente, afinal mesmo que tenhamos que separar problemas pessoais e do trabalho, na maioria das vezes isso não é tão simples e acaba afetando muito o processo produtivo. Um enfermeiro que consegue lidar com estas questões contribui para construção de uma boa equipe de enfermagem. 


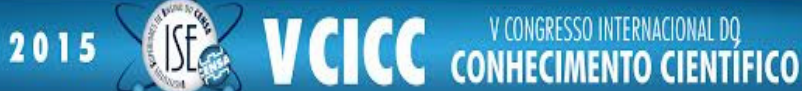

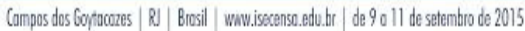

Palavras chave: Enfermagem; Psicologia; Cuidar.

\section{REFERÊNCIAS}

MELO, C.S.B.DE.; MIRANDA, R.; CIRINO, S.D.; CAMPOS, R.H. DE F. Estud. pesqui. psicol (Impr.); 14(1): 337-354, jan.-abr. 2014. 